\title{
Analysis of Critical Success Factors for PDM System Implementation Based on DEMATEL Method
}

\author{
Yong Cen \\ Information Center, China Tobacco Zhejiang Industrial Co., Ltd., Hangzhou 310009, China
}

\begin{abstract}
Product data management system implementation is a complex systems engineering, and influenced by many factors that influence each other and function. In order to identify the critical success factors, through an extensive review of the literature, total of $\mathbf{2 1}$ factors for the successful PDM system implementation are collected, and uses DEMATEL approach to visualize the structure of complicated causal relationships between these CSFs and obtain the influence level of these factors. According to the results of proposed method, eight critical success factors are figured out, such as top management support, project management, intensive education and training, key user involvement, project scope and goals, implementation approach, change management and business process reengineering. All these factors can be achieved in a stepwise way for better promoting the effectiveness and efficiency of PDM implementation.
\end{abstract}

Keywords—product data management; system implementation; critical success factors; DEMATEL method

\section{INTRODUCTION}

The Product Data Management system is designed to manage and store information about product data and their entire life cycle, is a tool to assist in managing data during product research and development, and ensures that design, manufacturing data and information are tracked to support and maintain the product [1]. In recent years, tobacco industry enterprises have carried out a lot of work on the implementation and expansion of PDM system, which has played an important role in improving the design and development of cigarette products, quality control and evaluation, and improving the management level [2-4]. Product data management is not a general sense of application and innovation of information technology. It is a management revolution with a high level. The implementation of PDM system is a complex system engineering. The successful implementation of PDM system requires the integration of PDM technical knowledge, business knowledge and the specific environment of the enterprise. From the past experience of PDM implementation, the successful implementation of PDM system depends more on the method and process of implementation than on technical problems [5]. Therefore, in-depth study of the relationship between the implementation of the PDM system and various factors affecting the implementation and identification of key factors is of great practical significance for the implementation of the system construction of tobacco industry enterprises. The main idea of this paper is to use the Decision Making Trial and Evaluation Laboratory (DEMATEL) to attempt to systematically answer the interrelationships between the factors affecting the implementation of the PDM system and identify the key success factors.

\section{RESEARCH METHODS}

\section{A. The Choice of Influencing Factors}

Based on literature research methods, this article collates the relevant factors of IT projects. Yong Cen and Hong-lv Wang analyzed the key factors of management and technology in the implementation of PDM system in tobacco industry enterprises; [5] Christian and Lars have combed out 24 important factors that influence IT project construction through a lot of literature research [6], Luo Rong and Yang Fangyan have analyzed various non-technical factors in the process of PDM implementation, and have established PDM stratified implementation model on this basis. This model can clearly express the relationship between various technical and nontechnical factors in the implementation of PDM [7]. Zhang Rong established the PDM layered implementation model, which can clearly express the links between various technical and non-technical factors in PDM implementation, and analyzes various non-technical factors in the implementation process of PDM [8]; Ao Yan analyzed the problems existing in the implementation of PDM projects in China's enterprises, and summed up the key success factors of PDM project implementation [9]. According to the above research, 21 key factors were identified for the more cited factors, as shown in Table 1. 
TABLE I. INFLUENCE FACTORS FOR SELECTION

\begin{tabular}{|c|c|c|c|}
\hline $\begin{array}{l}\text { Factor's } \\
\text { ID }\end{array}$ & $\begin{array}{l}\text { Influencing factors } \\
\text { (CSFs) }\end{array}$ & $\begin{array}{l}\text { Factor's } \\
\text { ID }\end{array}$ & $\begin{array}{c}\text { Influencing } \\
\text { factors (CSFs) }\end{array}$ \\
\hline C1 & Project management & C12 & $\begin{array}{l}\text { The fit with } \\
\text { company strategy }\end{array}$ \\
\hline C2 & $\begin{array}{c}\text { High-level corporate } \\
\text { support }\end{array}$ & C13 & $\begin{array}{c}\text { Change } \\
\text { Management }\end{array}$ \\
\hline C3 & $\begin{array}{c}\text { Reengineering business } \\
\text { processes }\end{array}$ & C14 & $\begin{array}{c}\text { Team } \\
\text { organization }\end{array}$ \\
\hline C4 & $\begin{array}{l}\text { Resource Management } \\
\text { (project budget, human } \\
\text { resources, etc.) }\end{array}$ & C15 & Software selection \\
\hline C5 & $\begin{array}{c}\text { Key users' } \\
\text { participation }\end{array}$ & C16 & $\begin{array}{l}\text { The quality of the } \\
\text { data }\end{array}$ \\
\hline C6 & $\begin{array}{l}\text { Knowledge and } \\
\text { experience }\end{array}$ & C17 & $\begin{array}{c}\text { Project scope and } \\
\text { objectives }\end{array}$ \\
\hline C7 & leadership & C18 & Risk Management \\
\hline C8 & $\begin{array}{l}\text { Continuous employee } \\
\text { training and education }\end{array}$ & C19 & company culture \\
\hline C9 & $\begin{array}{c}\text { Scientific and } \\
\text { reasonable BOM } \\
\text { management structure }\end{array}$ & $\mathrm{C} 20$ & The right solution \\
\hline C10 & $\begin{array}{c}\text { Method of } \\
\text { implementation }\end{array}$ & C21 & $\begin{array}{c}\text { Suppliers and } \\
\text { consultants }\end{array}$ \\
\hline C11 & $\begin{array}{c}\text { Effective } \\
\text { communication } \\
\text { mechanism }\end{array}$ & & \\
\hline
\end{tabular}

\section{B. DEMATEL Methods}

DEMATEL method is a common method to study the relationship among various factors in a complex system. It can not only effectively analyze the degree of interaction between various factors in a complex system, but also determine the primary and secondary relationship between factors based on the direct influence matrix. [10-12]. This paper uses the DEMATEL method to study the interrelationships of factors in a complex system as follows:

Step 1: Get the initial direct influence matrix. A group of experts is organized, and each expert separately scores the degree of influence among the various factors in the system to generate the initial direct influence matrix $C=\left[c_{i j}\right]$, which is a $n \times n$ non-negative matrix, ${ }^{C_{i j}}$ indicates the direct influence of factors $i$ on the factors $j$; When $i$ is equal to $j$, the diagonal element value is $c_{i j}=0$.

Step 2: Calculate the normalized direct influence matrix and the comprehensive influence matrix. Find the sum of the rows and columns that directly affect the matrix $C$.The normalized direct influence matrix $D=\left[d_{i j}\right]$ is obtained by formula (1). All the elements in the matrix are required to satisfied $0 \leq d_{i j} \leq 1$. All the elements on the main diagonal are equal to zero.

$$
D=\frac{1}{\max \left(\max \sum_{i=1}^{n} c_{i j}, \max \sum_{j=1}^{n} c_{i j}\right)} C
$$

Step 3: Calculate the general relationship matrix $T$. Calculate the general relation matrix by Equation (2), where $I$ is a unit matrix of $n \times n$.

$$
T=D(I-D)^{-1}
$$

Step 4: calculate the degree of direct and indirect influence of the factors in the total relational matrix $T$. The sum of the rows $D_{i}$ and the sum of columns $R_{j}$ of the matrix is calculated by formula 3) and formula 4, Among them, Di denotes the total sum of the direct and indirect effects of $i$ factors on other factors in the system, which is called impact degree; and $R_{j}$ denotes the sum of the direct and indirect effects of $\mathrm{j}$ factors on other factors in the system, which is called the influenced degree .

$$
\begin{aligned}
& D_{i}=\sum_{1 \leq j \leq n} t_{i j} \\
& R_{j}=\sum_{1 \leq i \leq n} t_{i j}
\end{aligned}
$$

When $\mathrm{i}$ is equal to $\mathrm{j}, D_{i}+R_{i}$ denotes the degree of relationship between factors, which we call the centrality; $D_{i}-R_{i}$ denotes the extent to which a factor affects or is affected, which we call it the cause degree. If $D_{i}-R_{i}$ is a positive number, it indicates that the degree of influence of factor $i$ on other factors is greater than the influence of other factors on $i$. At this time, factor $i$ is called the cause factor; If $D_{i}-R_{i}$ is a negative number, factor $\mathrm{i}$ is called the result factor.

Step 5: Build a causality diagram based on $D_{i}+R_{i}$ and $D_{i}-R_{i}$. By drawing a causality diagram for $\left(D_{i}+R_{i}\right.$, $D_{i}-R_{i}$ ), you can visualize the complex relationships between the influencing factors.

\section{RESULTS AND DISCUSSION}

\section{A. Calculations Based on the DEMATEL Method}

The DEMATEL method is used to study the main calculation processes that affect the interrelationships between PDM system implementation factors and identify key factors.

First, the design of the questionnaire and the evaluation of the expert group. In order to obtain the mutual influence of 21 influencing factors, five informatization and business experts who participated in the PDM system implementation in the enterprise were invited to form a group of experts to select and 
evaluate (1-No effect, 2-Effect is small, 3-Effect is not significant, 4-Effect is greater, 5-Effect is large), and direct influence matrix is obtained.
Second, the standardization of the direct influence matrix is standardized to directly affect the matrix, as shown in Table 2

\section{TABLE II. NORMALIZED DIRECT INFLUENCE MATRIX}

\begin{tabular}{|c|c|c|c|c|c|c|c|c|c|c|c|c|c|c|c|c|c|c|c|c|c|}
\hline Factors & C1 & C2 & C3 & C4 & C5 & C6 & C7 & C8 & C9 & C10 & C11 & C12 & C13 & C14 & C15 & C16 & C17 & C18 & C19 & C20 & C21 \\
\hline C1 & 0.000 & 0.039 & 0.055 & 0.039 & 0.055 & 0.024 & 0.024 & 0.055 & 0.039 & 0.055 & 0.055 & 0.039 & 0.039 & 0.047 & 0.008 & 0.047 & 0.047 & 0.055 & 0.016 & 0.024 & 0.016 \\
\hline C2 & 0.071 & 0.000 & 0.055 & 0.063 & 0.055 & 0.024 & 0.039 & 0.055 & 0.039 & 0.063 & 0.063 & 0.055 & 0.055 & 0.055 & 0.039 & 0.039 & 0.055 & 0.055 & 0.047 & 0.047 & 0.024 \\
\hline C3 & 0.039 & 0.055 & 0.000 & 0.047 & 0.039 & 0.016 & 0.008 & 0.024 & 0.047 & 0.039 & 0.024 & 0.039 & 0.024 & 0.024 & 0.055 & 0.024 & 0.055 & 0.047 & 0.016 & 0.024 & 0.024 \\
\hline C4 & 0.047 & 0.024 & 0.055 & 0.000 & 0.024 & 0.024 & 0.016 & 0.047 & 0.024 & 0.032 & 0.024 & 0.024 & 0.024 & 0.032 & 0.039 & 0.024 & 0.047 & 0.047 & 0.024 & 0.032 & 0.055 \\
\hline C5 & 0.047 & 0.024 & 0.063 & 0.024 & 0.000 & 0.032 & 0.024 & 0.055 & 0.063 & 0.047 & 0.032 & 0.032 & 0.055 & 0.047 & 0.024 & 0.063 & 0.016 & 0.032 & 0.016 & 0.039 & 0.008 \\
\hline C6 & 0.032 & 0.024 & 0.047 & 0.016 & 0.039 & 0.000 & 0.008 & 0.016 & 0.047 & 0.039 & 0.039 & 0.032 & 0.032 & 0.024 & 0.016 & 0.039 & 0.024 & 0.039 & 0.016 & 0.039 & 0.016 \\
\hline C7 & 0.055 & 0.039 & 0.039 & 0.016 & 0.016 & 0.024 & 0.000 & 0.024 & 0.024 & 0.039 & 0.039 & 0.032 & 0.039 & 0.016 & 0.008 & 0.032 & 0.016 & 0.039 & 0.008 & 0.039 & 0.016 \\
\hline C8 & 0.032 & 0.024 & 0.032 & 0.024 & 0.039 & 0.063 & 0.024 & 0.000 & 0.039 & 0.055 & 0.055 & 0.047 & 0.063 & 0.039 & 0.039 & 0.055 & 0.024 & 0.039 & 0.016 & 0.055 & 0.024 \\
\hline C9 & 0.024 & 0.016 & 0.063 & 0.024 & 0.024 & 0.032 & 0.016 & 0.024 & 0.000 & 0.055 & 0.024 & 0.024 & 0.047 & 0.024 & 0.032 & 0.055 & 0.016 & 0.055 & 0.016 & 0.055 & 0.016 \\
\hline C10 & 0.039 & 0.032 & 0.055 & 0.024 & 0.039 & 0.016 & 0.008 & 0.032 & 0.047 & 0.000 & 0.039 & 0.016 & 0.032 & 0.024 & 0.024 & 0.047 & 0.032 & 0.047 & 0.039 & 0.039 & 0.024 \\
\hline C11 & 0.039 & 0.032 & 0.016 & 0.016 & 0.039 & 0.024 & 0.039 & 0.016 & 0.008 & 0.047 & 0.000 & 0.008 & 0.032 & 0.016 & 0.008 & 0.016 & 0.008 & 0.047 & 0.008 & 0.032 & 0.032 \\
\hline C12 & 0.024 & 0.039 & 0.016 & 0.039 & 0.024 & 0.016 & 0.008 & 0.024 & 0.024 & 0.032 & 0.032 & 0.000 & 0.047 & 0.024 & 0.024 & 0.016 & 0.032 & 0.016 & 0.032 & 0.039 & 0.016 \\
\hline C13 & 0.032 & 0.039 & 0.024 & 0.039 & 0.032 & 0.032 & 0.039 & 0.032 & 0.039 & 0.055 & 0.032 & 0.055 & 0.000 & 0.024 & 0.016 & 0.024 & 0.047 & 0.055 & 0.047 & 0.055 & 0.024 \\
\hline C14 & 0.032 & 0.032 & 0.024 & 0.024 & 0.039 & 0.016 & 0.024 & 0.024 & 0.016 & 0.039 & 0.039 & 0.024 & 0.039 & 0.000 & 0.016 & 0.039 & 0.024 & 0.039 & 0.024 & 0.047 & 0.024 \\
\hline C15 & 0.016 & 0.008 & 0.032 & 0.039 & 0.016 & 0.016 & 0.008 & 0.024 & 0.047 & 0.032 & 0.016 & 0.039 & 0.032 & 0.016 & 0.000 & 0.008 & 0.032 & 0.024 & 0.008 & 0.032 & 0.039 \\
\hline C16 & 0.016 & 0.016 & 0.024 & 0.008 & 0.016 & 0.016 & 0.008 & 0.024 & 0.039 & 0.024 & 0.016 & 0.008 & 0.016 & 0.008 & 0.008 & 0.000 & 0.024 & 0.047 & 0.016 & 0.024 & 0.016 \\
\hline C17 & 0.039 & 0.047 & 0.039 & 0.063 & 0.039 & 0.016 & 0.016 & 0.016 & 0.016 & 0.063 & 0.024 & 0.039 & 0.039 & 0.047 & 0.024 & 0.016 & 0.000 & 0.047 & 0.016 & 0.039 & 0.024 \\
\hline C18 & 0.047 & 0.047 & 0.016 & 0.024 & 0.016 & 0.016 & 0.008 & 0.024 & 0.016 & 0.039 & 0.016 & 0.016 & 0.024 & 0.016 & 0.008 & 0.008 & 0.047 & 0.000 & 0.008 & 0.032 & 0.008 \\
\hline C19 & 0.024 & 0.032 & 0.016 & 0.024 & 0.039 & 0.016 & 0.016 & 0.032 & 0.008 & 0.016 & 0.032 & 0.024 & 0.032 & 0.016 & 0.008 & 0.024 & 0.016 & 0.032 & 0.000 & 0.032 & 0.008 \\
\hline C20 & 0.016 & 0.032 & 0.008 & 0.039 & 0.024 & 0.016 & 0.032 & 0.024 & 0.055 & 0.055 & 0.016 & 0.024 & 0.055 & 0.024 & 0.016 & 0.055 & 0.024 & 0.055 & 0.016 & 0.000 & 0.024 \\
\hline C21 & 0.024 & 0.024 & 0.039 & 0.016 & 0.016 & 0.047 & 0.039 & 0.016 & 0.024 & 0.032 & 0.039 & 0.024 & 0.024 & 0.039 & 0.047 & 0.024 & 0.016 & 0.039 & 0.008 & 0.039 & 0.000 \\
\hline
\end{tabular}

Third, the calculation of the DEMATEL method for the correlation between factors. Using Scilab5.5.1 to perform the matrix calculation of equation (2), the comprehensive impact influence matrix can be obtained, as shown in Table 3.

TABLE III. OVERALL RELATIONSHIP MATRIX

\begin{tabular}{|c|c|c|c|c|c|c|c|c|c|c|c|c|c|c|c|c|c|c|c|c|c|}
\hline Factors & C1 & $\mathrm{C} 2$ & C3 & $\mathrm{C} 4$ & C5 & C6 & C7 & C8 & C9 & C10 & C11 & C12 & C13 & C14 & C15 & C16 & C17 & C18 & C19 & C20 & C21 \\
\hline C1 & 0.071 & 0.103 & 0.125 & 0.100 & 0.117 & 0.071 & 0.063 & 0.112 & 0.105 & 0.140 & 0.118 & 0.071 & 0.103 & 0.125 & 0.100 & 0.117 & 0.071 & 0.063 & 0.112 & 0.105 & 0.140 \\
\hline C2 & 0.156 & 0.082 & 0.143 & 0.139 & 0.134 & 0.083 & 0.089 & 0.129 & 0.123 & 0.170 & 0.142 & 0.156 & 0.082 & 0.143 & 0.139 & 0.134 & 0.083 & 0.089 & 0.129 & 0.123 & 0.170 \\
\hline C3 & 0.099 & 0.108 & 0.064 & 0.101 & 0.093 & 0.057 & 0.043 & 0.076 & 0.104 & 0.114 & 0.079 & 0.099 & 0.108 & 0.064 & 0.101 & 0.093 & 0.057 & 0.043 & 0.076 & 0.104 & 0.114 \\
\hline $\mathrm{C} 4$ & 0.104 & 0.078 & 0.113 & 0.053 & 0.077 & 0.064 & 0.050 & 0.095 & 0.080 & 0.104 & 0.078 & 0.104 & 0.078 & 0.113 & 0.053 & 0.077 & 0.064 & 0.050 & 0.095 & 0.080 & 0.104 \\
\hline C5 & 0.110 & 0.083 & 0.128 & 0.081 & 0.060 & 0.076 & 0.061 & 0.109 & 0.126 & 0.128 & 0.091 & 0.110 & 0.083 & 0.128 & 0.081 & 0.060 & 0.076 & 0.061 & 0.109 & 0.126 & 0.128 \\
\hline C6 & 0.082 & 0.071 & 0.099 & 0.062 & 0.085 & 0.035 & 0.038 & 0.060 & 0.096 & 0.103 & 0.085 & 0.082 & 0.071 & 0.099 & 0.062 & 0.085 & 0.035 & 0.038 & 0.060 & 0.096 & 0.103 \\
\hline C7 & 0.104 & 0.086 & 0.090 & 0.061 & 0.063 & 0.058 & 0.030 & 0.067 & 0.073 & 0.102 & 0.086 & 0.104 & 0.086 & 0.090 & 0.061 & 0.063 & 0.058 & 0.030 & 0.067 & 0.073 & 0.102 \\
\hline C8 & 0.098 & 0.085 & 0.100 & 0.083 & 0.100 & 0.107 & 0.063 & 0.057 & 0.106 & 0.138 & 0.116 & 0.098 & 0.085 & 0.100 & 0.083 & 0.100 & 0.107 & 0.063 & 0.057 & 0.106 & 0.138 \\
\hline C9 & 0.078 & 0.067 & 0.116 & 0.072 & 0.073 & 0.068 & 0.047 & 0.070 & 0.056 & 0.122 & 0.073 & 0.078 & 0.067 & 0.116 & 0.072 & 0.073 & 0.068 & 0.047 & 0.070 & 0.056 & 0.122 \\
\hline C10 & 0.096 & 0.084 & 0.112 & 0.075 & 0.091 & 0.055 & 0.042 & 0.080 & 0.102 & 0.072 & 0.091 & 0.096 & 0.084 & 0.112 & 0.075 & 0.091 & 0.055 & 0.042 & 0.080 & 0.102 & 0.072 \\
\hline C11 & 0.083 & 0.071 & 0.061 & 0.054 & 0.078 & 0.053 & 0.064 & 0.054 & 0.051 & 0.100 & 0.042 & 0.083 & 0.071 & 0.061 & 0.054 & 0.078 & 0.053 & 0.064 & 0.054 & 0.051 & 0.100 \\
\hline C12 & 0.071 & 0.081 & 0.064 & 0.081 & 0.067 & 0.048 & 0.037 & 0.064 & 0.069 & 0.090 & 0.075 & 0.071 & 0.081 & 0.064 & 0.081 & 0.067 & 0.048 & 0.037 & 0.064 & 0.069 & 0.090 \\
\hline $\mathrm{C} 13$ & 0.097 & 0.099 & 0.090 & 0.097 & 0.090 & 0.075 & 0.076 & 0.086 & 0.100 & 0.134 & 0.091 & 0.097 & 0.099 & 0.090 & 0.097 & 0.090 & 0.075 & 0.076 & 0.086 & 0.100 & 0.134 \\
\hline C14 & 0.083 & 0.078 & 0.076 & 0.069 & 0.085 & 0.051 & 0.054 & 0.068 & 0.066 & 0.103 & 0.086 & 0.083 & 0.078 & 0.076 & 0.069 & 0.085 & 0.051 & 0.054 & 0.068 & 0.066 & 0.103 \\
\hline C15 & 0.058 & 0.047 & 0.075 & 0.077 & 0.054 & 0.046 & 0.033 & 0.059 & 0.087 & 0.084 & 0.055 & 0.058 & 0.047 & 0.075 & 0.077 & 0.054 & 0.046 & 0.033 & 0.059 & 0.087 & 0.084 \\
\hline C16 & 0.049 & 0.046 & 0.057 & 0.037 & 0.046 & 0.038 & 0.027 & 0.051 & 0.070 & 0.065 & 0.046 & 0.049 & 0.046 & 0.057 & 0.037 & 0.046 & 0.038 & 0.027 & 0.051 & 0.070 & 0.065 \\
\hline C17 & 0.100 & 0.102 & 0.101 & 0.116 & 0.094 & 0.056 & 0.051 & 0.069 & 0.075 & 0.136 & 0.080 & 0.100 & 0.102 & 0.101 & 0.116 & 0.094 & 0.056 & 0.051 & 0.069 & 0.075 & 0.136 \\
\hline C18 & 0.088 & 0.084 & 0.059 & 0.062 & 0.055 & 0.044 & 0.032 & 0.059 & 0.056 & 0.091 & 0.055 & 0.088 & 0.084 & 0.059 & 0.062 & 0.055 & 0.044 & 0.032 & 0.059 & 0.056 & 0.091 \\
\hline C19 & 0.064 & 0.068 & 0.056 & 0.059 & 0.075 & 0.043 & 0.040 & 0.066 & 0.047 & 0.066 & 0.068 & 0.064 & 0.068 & 0.056 & 0.059 & 0.075 & 0.043 & 0.040 & 0.066 & 0.047 & 0.066 \\
\hline C20 & 0.070 & 0.079 & 0.064 & 0.085 & 0.071 & 0.052 & 0.061 & 0.069 & 0.105 & 0.119 & 0.065 & 0.070 & 0.079 & 0.064 & 0.085 & 0.071 & 0.052 & 0.061 & 0.069 & 0.105 & 0.119 \\
\hline C21 & 0.073 & 0.069 & 0.089 & 0.060 & 0.061 & 0.079 & 0.067 & 0.057 & 0.072 & 0.093 & 0.084 & 0.073 & 0.069 & 0.089 & 0.060 & 0.061 & 0.079 & 0.067 & 0.057 & 0.072 & 0.093 \\
\hline
\end{tabular}


Fourthly, according to equations (3) and (4), the sum of matrix sums and matrix sums are calculated, respectively, and the degree of influence of the influencing factor, the degree of influenced, the degree of centrality, and the cause degree are obtained. As shown in Table 4.

TABLE IV. TABLE TYPE STYLES

\begin{tabular}{|c|c|c|c|c|c|c|c|c|c|}
\hline \multirow{2}{*}{ Factors } & \multirow{2}{*}{$\begin{array}{l}\text { Influencing } \\
\text { factors }\end{array}$} & \multicolumn{2}{|c|}{ Influence Factor D } & \multicolumn{2}{|c|}{ Degree Influenced R } & \multicolumn{2}{|c|}{$\begin{array}{c}\text { Degree Centrality } \\
\text { D+R }\end{array}$} & \multicolumn{2}{|c|}{$\begin{array}{c}\text { Cause Degree } \\
\text { D-R }\end{array}$} \\
\hline & & Result & Rank & Result & Rank & Result & Rank & Result & Rank \\
\hline C1 & $\begin{array}{c}\text { Project } \\
\text { management }\end{array}$ & 2.068 & 2 & 1.835 & 6 & 3.903 & 4 & 0.233 & 7 \\
\hline C2 & $\begin{array}{c}\text { High-level } \\
\text { corporate support }\end{array}$ & 2.619 & 1 & 1.669 & 11 & 4.288 & 1 & 0.951 & 1 \\
\hline C3 & $\begin{array}{c}\text { Reengineering } \\
\text { business } \\
\text { processes }\end{array}$ & 1.796 & 7 & 1.882 & 5 & 3.678 & 5 & -0.086 & 14 \\
\hline $\mathrm{C} 4$ & $\begin{array}{c}\text { Resource } \\
\text { Management } \\
\text { (project budget, } \\
\text { human resources, } \\
\text { etc.) }\end{array}$ & 1.751 & 8 & 1.622 & 13 & 3.373 & 12 & 0.130 & 9 \\
\hline C5 & $\begin{array}{c}\text { Key users’ } \\
\text { participation }\end{array}$ & 1.954 & 4 & 1.673 & 10 & 3.627 & 6 & 0.281 & 5 \\
\hline C6 & $\begin{array}{c}\text { Knowledge and } \\
\text { experience }\end{array}$ & 1.537 & 13 & 1.259 & 17 & 2.796 & 16 & 0.277 & 6 \\
\hline $\mathrm{C} 7$ & leadership & 1.506 & 14 & 1.067 & 21 & 2.573 & 19 & 0.439 & 3 \\
\hline C8 & $\begin{array}{l}\text { Continuous } \\
\text { employee } \\
\text { training and } \\
\text { education } \\
\end{array}$ & 2.040 & 3 & 1.557 & 15 & 3.597 & 7 & 0.483 & 2 \\
\hline C9 & $\begin{array}{l}\text { Scientific and } \\
\text { reasonable BOM } \\
\text { management } \\
\text { structure }\end{array}$ & 1.656 & 10 & 1.770 & 7 & 3.426 & 11 & -0.113 & 15 \\
\hline C10 & $\begin{array}{c}\text { Method of } \\
\text { implementation }\end{array}$ & 1.720 & 9 & 2.275 & 2 & 3.995 & 2 & -0.554 & 19 \\
\hline C11 & $\begin{array}{c}\text { Effective } \\
\text { communication } \\
\text { mechanism }\end{array}$ & 1.300 & 17 & 1.705 & 9 & 3.005 & 14 & -0.405 & 17 \\
\hline C12 & $\begin{array}{c}\text { The fit with } \\
\text { company strategy }\end{array}$ & 1.407 & 16 & 1.570 & 14 & 2.977 & 15 & -0.163 & 16 \\
\hline $\mathrm{C} 13$ & $\begin{array}{c}\text { Change } \\
\text { Management }\end{array}$ & 1.944 & 5 & 1.963 & 4 & 3.907 & 3 & -0.020 & 13 \\
\hline C14 & $\begin{array}{c}\text { Team } \\
\text { organization }\end{array}$ & 1.542 & 12 & 1.481 & 16 & 3.023 & 13 & 0.061 & 12 \\
\hline C15 & $\begin{array}{l}\text { Software } \\
\text { selection }\end{array}$ & 1.280 & 18 & 1.212 & 18 & 2.492 & 20 & 0.068 & 11 \\
\hline C16 & $\begin{array}{l}\text { The quality of the } \\
\text { data }\end{array}$ & 0.985 & 21 & 1.740 & 8 & 2.726 & 17 & -0.755 & 20 \\
\hline C17 & $\begin{array}{l}\text { Project scope and } \\
\text { objectives }\end{array}$ & 1.803 & 6 & 1.626 & 12 & 3.429 & 10 & 0.176 & 8 \\
\hline C18 & $\begin{array}{c}\text { Risk } \\
\text { Management }\end{array}$ & 1.220 & 19 & 2.276 & 1 & 3.496 & 9 & -1.056 & 21 \\
\hline C19 & company culture & 1.193 & 20 & 1.078 & 20 & 2.271 & 21 & 0.115 & 10 \\
\hline $\mathrm{C} 20$ & The right solution & 1.592 & 11 & 2.000 & 3 & 3.592 & 8 & -0.408 & 18 \\
\hline $\mathrm{C} 21$ & $\begin{array}{c}\text { Suppliers and } \\
\text { consultants }\end{array}$ & 1.495 & 15 & 1.150 & 19 & 2.646 & 18 & 0.345 & 4 \\
\hline
\end{tabular}

According to the calculation results in Table 4, the results of the PDM system implementation factors are shown in Figure 1. 


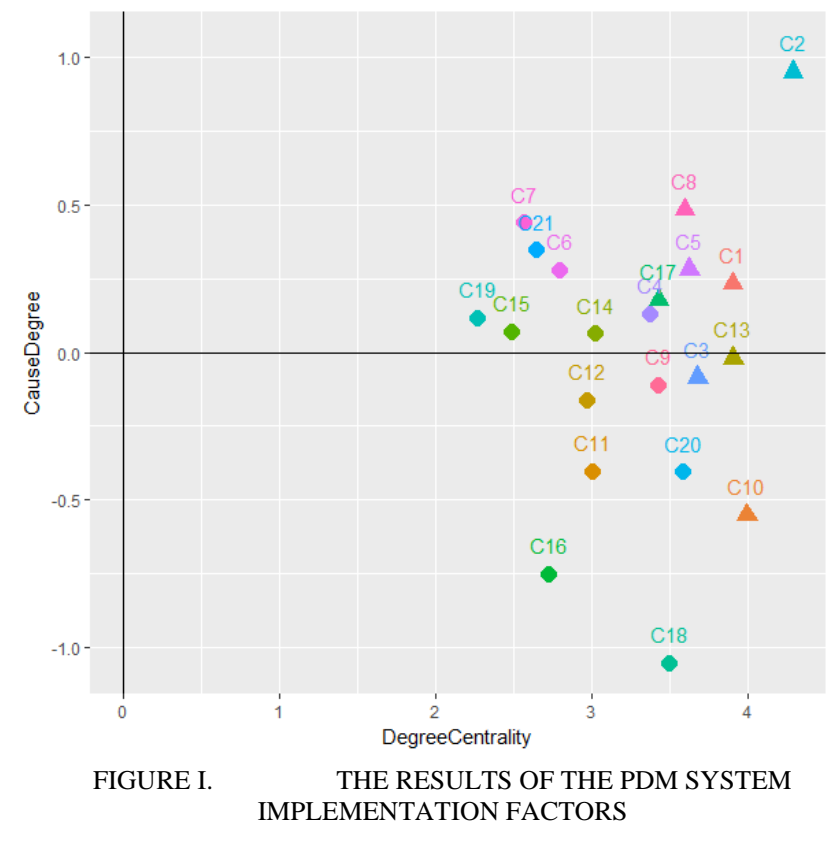

\section{B. Identification of Key Factors}

\section{1) Interrelationships between Factors}

It can be clearly seen from Table 4 and FIG. 1 that factors C1, C2, C4, C5, C6, C7, C8, C14, C17, C19, and C21 are the cause factors. The highest level of corporate support (C2) has the highest degree of influence, but the degree of influenced ranks 11th out of the 21 factors, indicating that high-level corporate support can strongly influence other factors, but it is difficult for itself to be affected by other factors., which shows a strong initiative. Similarly, continuous training and education for employees (C8) and project scope and goals (C17) are also among the more active factors. Factors C3, C9, C10, C11, C12, C13, C16, C18 and C20 are the result factors. Risk management (C18) and implementation method (C10) were ranked first and second in terms of degree of influence, and essentially exhibited strong passiveness. Business process reengineering (C3) and change management (C13) ranked in the 5th, 4th, 7th, and 5th places in terms of influence and influenced respectively, indicating that these two factors are also closely related to other factors.

\section{2) Interrelationships between Factors}

Cause factors have a great influence on the network performance of the entire system, so it is generally believed that these factors should be taken seriously. The impact of high-level corporate support (C2), project management (C1) and continuous employee training and education (C8) was 2.61944, 2.06804, and 2.04013, ranking first, second, and third respectively, and affecting the other 18 factors. The factors can therefore be confirmed as a key factor. The level of key user engagement (C5) and project scope and target (C17) ranked fourth and sixth in terms of impact degree, and had a higher degree of centrality, ranking sixth and tenth, respectively, in the system. The greater role played is obviously a key factor. The degree of influence of factor resource management (C4) is 1.75143. It ranks eighth in the influence of 21 factors, but ranks 13th in the degree of influence, indicating that it has an impact on other factors, but it is also easy. Affected by other factors, in addition, the centrality corresponding to this factor ranks the twelfth among all factors, and the role played in the system is not very large. Therefore, resource management (C4) may not be considered as a key factor. Similarly, C6, C7, C14, C15, C19, and C21 may all be considered not critical factors.

\section{3) Analysis of Outcome Factors}

Generally speaking, the outcome factors are easily influenced by other factors, which makes the result factors unsuitable as a key factor. However, it is still worth the necessary discussion of the outcome factors in order to identify their characteristics. The implementation method (C10), change management (C13), and business process reengineering (C3), although they are the result factors, rank second, third, and fifth respectively in the center, indicating that they play a larger role in the system. At the same time, the degree of influence and the degree of influenced of these three factors are also the ninth and the second, the fifth and the fourth, the seventh and the fifth of the 21 factors respectively, which obviously have important influence in the system. Therefore, C10, C13 and C3 are the key factors. Risk management C18) ranks first among all 21 factors, indicating that it is highly vulnerable to other factors and is clearly not a key factor. A scientific and rational BOM management framework (C9), an effective communication mechanism (C11), a corporate strategic fit (C12), a data quality (C16) and an appropriate solution (C20) have common characteristics, namely, their small impact and centrality. It is considered that C9, C11, C12, C16 and C20 are not key factors.

\section{CONCLUSION}

In summary, this paper uses DEMATEL method to determine the importance of various factors affecting the implementation of the PDM system under uncertain circumstances, and analyzes the causal relationships between the various factors, and ultimately identifies the key success factors. The main conclusions of the study are: First, the 21 factors that affect the successful implementation of the PDM system are intertwined and together constitute a very complex system. Second, different factors have different degrees of influence, methods, and mechanisms. Third, out of 21 factors, high-level corporate support, project management, continuous employee training and education, key user engagement, project scope and goals, implementation methods, change management, and business process reengineering are among the 8 key success factors. Through the identification of key success factors, it can help business decision makers to formulate better implementation strategies to ensure the successful implementation of PDM systems under constraints of limited resources.

\section{REFERENCES}

[1] BENOIT EYNARD, THOMAS GALLET, LIONEL ROUCOULES, et al. "PDM system implementation based on UML", Mathematics and Computers in Simulation, 2006, Vol.70, pp. 330-342.

[2] CEN Yong, WANG Honglü, ZHANG Zhihua etc., "Design and Implementation of Cigarette Product Research and Development 
Management System in Tobacco Industrial Enterprise”, Tobacco Science \& Technology, 2013, Vol.11, pp. 25-30.

[3] ZHANG Hongming, SHEN Juming, LIN Yu etc., "Design and Application of PDM-based Cigarette Product R\&D Management System”, Tobacco Science \& Technology, 2013, Vol.6, pp. 24-27.

[4] WU LING, WEI WAN-ZHI, ZHONG KE-JUN, et al. "Development and Application of Cigarette Blending Expert System”, Tobacco Science \& Technology, 2002, Vol.12, pp. 8-10.

[5] YONG CEN, HONG-LV WANG. "Analysis on critical factors for PDM success implementation in Chinese tobacco industry enterprise", Advanced Materials Research, 2013, 765-767:, pp.3271-3276.

[6] CHRISTIAN LEYH, LARS CRENZE. "ERP System Implementations vs. IT Projects: Comparison of Critical Success Factors”, Enterprise Information Systems of the Future, 2013, Vol.139, pp.223-233.

[7] LUO Rong,YANG Fang-yan, "Research of the Non-Technology Factors Af fecting PDM Implement”, Manufacture Information Engineering of China, 2006, Vol. 23, pp. 740-741.

[8] ZHANG Rong. "Research of the Non-Technology Factors Affecting PDM Implement", Machine Building \& Automation, 2009, Vol. 4, pp. 116-118.

[9] Ao Yan. "Research on Key Success Factors and Risk Management of PDM Project”, Wuhan University of Science and Technology, 2011.

[10] LIN C. J., WU W. W. "A Causal Analytical Method for Group Decision Making Under Fuzzy Environment”, Expert Systems with Applications, 2008, Vol.34 (1), pp. 205- 213.

[11] WU Lin-hai, ZHANG Qiu-qin, SHAN Li-jie, et al. "Study on Identifying Critical Factors of Using Behavior of Food Additives in Enterprises: A Fuzzy DEMATEL Method”, Systems Engineering, 2012, Vol.7, pp. 48-54.

[12] Cui Qiang, Wu Chunyou, Kuang Haibo, et al. "Influencing factors identification of transportation low - carbonization capacity based on the RBF - DEMATEL model”, Science Research Management, 2013, Vol.10, pp. 131-137. 